\title{
Direitos humanos, neoconservadorismo e neofascismo no Brasil contemporâneo*
}

\author{
Human rights, neoconservatism and \\ neofascism in contemporary Brazil
}

\author{
Maria Lúcia da S. Barroco ${ }^{a}$ \\ (D) https://orcid.org/0000-0003-3165-1634
}

Resumo: Este texto aborda os fundamentos do neoconservadorismo e as características do neofascismo para situar a presença dessas ideologias e modos de ser na sociedade brasileira, no governo Bolsonaro.

Palavras-chaves: Neoconservadorismo. Neofascismo. Irracionalismo. Direitos humanos.
Abstract: This text addresses the foundations of neoconservatism and the characteristics of neofascism to situate the presence of these ideologies and ways of being in Brazilian society, during the Bolsonaro government.

Keywords: Neoconservatism. Neofascism. Irrationalism. Human rights.

*Este artigo é produto de palestra proferida no lançamento do livro Ética, direitos humanos e neoconservadorismo, em 15 de setembro de 2021, inserida nas comemorações dos 50 anos do Programa de Estudos Pós-Graduados em Serviço Social da PUC-SP.

aPontifícia Universidade Católica de São Paulo (PUC-SP), São Paulo/SP, Brasil.

Recebido: 15/9/2021 - Aprovado: 21/9/2021 


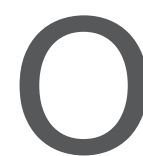
mundo contemporâneo vivencia a inserção da direita e da extrema-direita mundiais em funções políticas, seja em cargos governamentais e parlamentares, seja na direção de partidos políticos e movimentos sociais. Inscrita no processo de crise estrutural do capital e desenvolvendo-se sob formas particulares em cada país e conjuntura, essa rearticulação política tem gestado ideologias que resgatam os ideários fascista e conservador e se objetivam em novas combinações, a exemplo do neofascismo e do neoconservadorismo.

O neoconservadorismo consiste na junção entre os valores do conservadorismo moderno e os princípios do neoliberalismo. Do conservadorismo clássico, preservam-se a tradição, a experiência, o preconceito, a ordem, a hierarquia, a autoridade, valorizando-se as instituições tradicionais, como a igreja e a família patriarcal (Barroco, 2015).

As instituições são concebidas consolidadas num longo processo de evolução, no qual os valores - formados pelo hábito - são conservados pela tradição de forma permanente. Nesse sentido, são valores atemporais. Do neoliberalismo, conservam-se a não interferência do Estado na economia, o empreendedorismo, a meritocracia, o privatismo, o combate aos movimentos sociais e aos direitos sociais (Barroco, 2015).

Propostas neofascistas ${ }^{1}$ encontram ressonância num tempo em que o emprego é escasso e a competição toma o lugar da solidariedade; em que a barbárie dissemina o ódio e a desumanização; em que a brutalidade passa a ser virtude política e o irracionalismo apela aos piores instintos e às reservas de animalidade que brotam no indivíduo, na sociedade capitalista, como diz o filósofo Lukács (2007).

Combatendo o racionalismo, o coletivismo, o socialismo e o marxismo, o neoconservadorismo nega a viabilidade de projetos societários universais, considerando que as promessas de liberdade e igualdade irrestrita conduzem ao totalitarismo.

Existe um debate sobre a pertinência do uso do termo "neofascismo" que não cabe reproduzir neste artigo. Estou seguindo a orientação de Soares (2020), Stanley (2019) e Eco (2018). 
Para que a sociedade funcione de forma estável, defendem-se a garantia da ordem e o funcionamento das instituições fundadas na tradição e na autoridade constituída. Assim, a moral desempenha uma função de destaque na reprodução dos valores e da tradição, seja na socialização dos indivíduos, pela família, seja na manutenção da ordem espiritual, pelas religiões.

A extrema-direita mundial está unida em torno de algumas premissas: o nacionalismo e o patriotismo; o resgate de tradições; o anticomunismo e o antissemitismo; o racismo e a xenofobia contra imigrantes e minorias. A vida cotidiana é marcada por uma sociabilidade cindida entre "nós e eles", com a exaltação da família patriarcal e de seus valores, como a autoridade do pai; com a defesa da lei e da ordem; o anti-intelectualismo; a desarticulação do bem-estar público; a exclusão de grupos sociais minoritários e sua desumanização e/ou extermínio (Barroco, 2013).

A difusão e a legitimação social do neoconservadorismo de feições fascistas supõem a existência de condições sociais favoráveis, dadas em momentos de crise social, quando se acirram as tensões e a luta de classes, e o poder dominante utiliza mecanismos coercitivos para impor a ordem social (Barroco, 2013).

Segundo Lukács (2007), o irracionalismo contribui para transferir o enfrentamento dos conflitos para o campo do imaginário, dissimulando as determinações das contradições sociais, os seus nexos e mediações, naturalizando as suas consequências, negando a possibilidade de sua compreensão radical (Barroco, 2013).

Para ele, o fascismo, como concepção de mundo, é, antes de tudo, o apogeu qualitativo de teorias irracionalistas no domínio da epistemologia e aristocráticas nos planos social e moral; teorias que, nas ciências oficial e não oficial, bem como na divulgação científica e na pseudocientífica e no jornalismo, desempenham um papel importante há décadas (Lukács, 2007; Barroco, 2013).

Autores como Jason Stanley (2019) e Umberto Eco (2018) nos ajudam a entender o Brasil, especialmente o caráter neofascista do atual governo. 
Stanley analisa a era Trump, nos Estados Unidos, abordando a política do "nós" e "eles" como típica de regimes fascistas cujas características são, entre outras:

1. Referência a um passado mítico, valorizado em função da família patriarcal e de seus valores, como a autoridade do pai;

2. Anti-intelectualismo;

3. Defesa da lei e da ordem;

4. Desarticulação do bem-estar público;

5. Ansiedade sexual;

6. Exclusão de grupos sociais minoritários e sua desumanização e/ou extermínio precedido de ataques retóricos;

7. Divisão da população entre "nós e eles";

8. Nacionalismo.

Umberto Eco analisa os regimes fascistas na Europa, considerando que existem certas características típicas do que ele denomina "fascismo eterno". São elas:

1. Culto à tradição;

2. Recusa da modernidade: a ilustração e a razão são vistas como princípios de depravação moderna, podendo definir-se como irracionalismo;

3. O irracionalismo supõe o culto à ação pela ação, negando a reflexão;

4. Negação do espírito crítico, pois ele supõe o desacordo. Para o fascismo, desacordo é traição;

5. Negação da diferença e da diversidade. Por isso, o fascismo é racista por definição;

6. O fascismo surge da insatisfação individual ou social; por isso, uma das características típicas dos fascismos históricos é o chamamento às classes médias frustradas por alguma crise econômica, assustadas pela pressão dos grupos sociais subalternos; 
7. O nacionalismo e a xenofobia;

8. A negação da paz; a vida é uma guerra permanente;

9. O elitismo aristocrático e militarista;

10. O culto a um herói; o culto da morte;

11. A projeção da vontade de poder a questões sexuais; machismo, intolerância com as mulheres, com a homossexualidade;

12. Populismo qualitativo, os indivíduos não têm direitos; o líder se coloca como seu intérprete.

Robert Paxton (2007) caracteriza o fascismo salientando: 1) o culto à violência e ao militarismo; 2) a crença de que a salvação da pátria requer a eliminação dos inimigos internos por meio da mobilização permanente; 3) o uso da identidade nacional através de uma concepção agressiva de corpo social.

Observamos que o governo Bolsonaro reproduz vários supostos do neoconservadorismo, além das características neofascistas apontadas por Stanley, Eco e Paxton:

1. A referência a um passado mítico é objetivada pelo governo em função do mito de que a ditadura empresarial militar não existiu como tal, ou seja, como barbárie e horror. A criação de mitos, característica do irracionalismo e do fascismo, visa subjetivar a história, transformando-a em "verdades individuais", remetendo a outra característica do irracionalismo: o negacionismo em face da ciência e da história. $O$ negacionismo tem sido o método de refundação do real, de transformação de fake news em verdades.

2. Segundo Stanley e Eco, o anti-intelectualismo é uma característica dos regimes fascistas, expressando também o irracionalismo no desprestígio dado ao conhecimento acadêmico crítico, à cultura humanista e à educação, de modo geral;

3. A defesa da ordem, princípio conservador, tem caráter moral: objetiva-se no ataque moralista a conquistas dos movimentos de 
mulheres, negros, indígenas e da população LGBTQI+. O racismo, a homofobia, a transfobia e o preconceito de classe permeiam todas as ações de Bolsonaro, desde as mais sutis, como beber um copo de leite em suas lives, aludindo à supremacia branca (Soares, 2020).

4. A exclusão de grupos sociais em nome da ordem social também está voltada à perseguição política aos movimentos de esquerda, exclusão que, na fala do Presidente da República, deveria constituir na extinção. Antes da eleição, Bolsonaro afirmou que o erro da ditadura foi o de apenas torturar e não matar; "deveria ter matado pelo menos 30 mil”. O gozo com a morte é parte da teleologia da barbárie (Soares, 2020).

5. A ansiedade sexual é notória nos pronunciamentos do governo, cuja referência a situações que envolvem questões de gênero ou de orientação sexual é sistemática. A adesão a uma moral sexual machista e homofóbica tornou-se explícita com a divulgação dos mitos que criaram ideologicamente o chamado "kit gay" e deturparam a discussão de gênero nas escolas. Há uma obsessão irracionalista de Bolsonaro e de seus seguidores com o que chamam de "sexualidade precoce" provocada, segundo eles, pelos "comunistas" nos governos do PT, acusado de pretender perverter as crianças, transformá-las em homossexuais e jogá-las no inferno das drogas para dominar o mundo (Soares, 2020, p. 40).

6. O nacionalismo se manifesta na adesão às cores da bandeira brasileira, por parte dos apoiadores do governo, e nos lemas da campanha: Brasil acima de tudo;

7. A divisão entre "nós e eles" é evidente na sociedade brasileira, pelo menos desde as manifestações de 2013 e 2016. Bolsonaro incentiva o ódio ao se colocar contra o sistema, ou seja, contra as instituições democráticas, contra a Constituição. Sua performance com a arma na mão envolve uma estética da morte; o culto a um torturador tratado como herói incentiva o extravasamento do ódio, funcionando ideologicamente como uma licença para matar. Ao dar aval à violência, 
Bolsonaro autoriza as manifestações de ódio, os ressentimentos, os recalques; não é à toa que os crimes de ódio aumentaram de forma assustadora, especialmente os feminicídios;

8. Segundo Soares (2020), a apropriação do ódio pelos agentes políticos de extrema-direita leva a empregarem esse combustível para turbinar seus projetos. Num país onde o ódio seja o afeto predominante reinará quem o personificar, não tendo lugar para a diferença, para a tolerância, instaurando uma sociabilidade em que o outro será o inimigo e as instituições serão levadas a se militarizar;

9. A desarticulação do bem público ocorre no sucateamento dos direitos sociais e trabalhistas historicamente conquistados por trabalhadores e movimentos sociais, pela ofensiva antidemocrática, pela destruição da natureza, aprofundando a barbárie objetivada pela crise estrutural do capital;

10. O culto da morte, ao lado do culto da violência e do militarismo, é inerente ao projeto bolsonarista. Como analisa Soares, a liberação do acesso às armas, a condecoração de policiais acusados de assassinato, a celebração da brutalidade letal significam a restauração de um passado perdido com o fim da ditadura militar empresarial: "Bolsonaro é o messias que traz a salvação para o macho arquétipo" (Soares, 2020, p. 42).

11. A crença de que a salvação da pátria requer a eliminação dos inimigos internos por meio da mobilização permanente é reafirmada pelo governo Bolsonaro e por seus seguidores em sua constante alusão, e de seus ministros, aos comunistas que estariam prestes a tomar o poder no Brasil, reforçando a divisão fascista entre "nós" e "eles".

Dissemos que a defesa da ordem e da lei é um valor fundamental para os conservadores e neoconservadores. Historicamente, a ordem é tanto definida em função da "desordem" política causada pela luta de classes, pelas greves, pela recusa da dominação, como em termos morais, em função da defesa da família patriarcal, ante as "desordens" causadas 
por novas formas de relação afetiva, de orientação sexual, de ruptura com valores tradicionais etc.

No projeto bolsonarista, a ordem é majoritariamente defendida em termos moralizantes: trata-se de preservar a supremacia do macho, o casamento monogâmico (com a subordinação da mulher — dona de casa ao pai de família), a autoridade policial. No entanto, contradizendo sua perspectiva ultraconservadora, Bolsonaro não defende a severidade das leis. Para Soares, Bolsonaro não tem nada a ver com a defesa da lei, pois seu modelo é o miliciano, cuja lógica se assenta no poder autoconferido que só se deixa guiar por si mesmo, estando incutido em amplos segmentos das forças policiais. Diz ele:

\begin{abstract}
A história do Brasil racista e classista tem sido escrita todos os dias, exaltada e rememorada pela violência policial [...] a prática desses segmentos policiais tem escrito e reescrito a história na pele, no corpo (e no espírito) dos escravos, no dorso da sociedade (dorso pobre e negro) (Soares, 2020, p. 56).
\end{abstract}

Soares analisa a politização dos policiais e a rotina dos numerosíssimos segmentos infectados pelo bolsonarismo em todo o país, afirmando que o que os move não é a paixão pela ordem ou o cumprimento da lei, mas a exaltação tribal da guerra, a iminência da morte:

Os agentes não se reconhecem nas instituições, nem nas leis, nem na República, seja como ideia, seja como valor, e muito menos como prática - o cinismo mais cáustico prepondera, nenhum respeito à política, aquilo que denominam "sistema" é rechaçado. Só podem crer em si mesmos, em seus colegas, em sua missão, tal como a entendem e experimentam: autoatribuída. É o exercício da força que confere poder aos agentes que só se identificam com o poder autoconferido, ou seja, aquele que emana da arma, da intimidação, da violência. A violência contra pobres e negros não é tema lateral; é absolutamente central para a democracia, pois o poder autoconferido é a lógica da milícia (Soares, 2020, p. 56-57). 
Por fim, a negação da paz e a concepção de que a vida é uma guerra permanente, situadas por Eco, são notórias no modo de ser de Bolsonaro. É Soares que chama a atenção para esse dado, afirmando que a finalidade do projeto bolsonarista é destruir, o que significa que alcançada a destruição, o projeto anularia a si mesmo. Logo, a finalidade não é um objeto, mas uma ação: o verbo destruir. Nesse sentido, diz Soares (2020, p. 62):

[...] o que ele quer é o jogo, tanto quanto deseja a extinção do inimigo e o triunfo total, irreversível. Os dois objetivos, entretanto, se contradizem, daí o apreço às crises, sucessiva a artificialmente provocadas, daí a excitação com a tortura e o júbilo com a morte das vítimas, desde que o depósito de ovelhas sacrificiais seja sempre abastecido: o prazer infinito é a promessa do gozo inalcançável, a teleologia da barbárie.

Embora essas características apontem para uma ideologia neoconservadora e neofascista e para práticas de extrema-direita, sua penetração na sociedade atinge setores não necessariamente articulados com essas tendências, especialmente a ideologia do "nós e eles". Numa sociedade de raízes racistas fincadas na herança colonial escravocrata e na cultura patriarcal, esse éthos está inserido na estrutura da sociedade, reproduzindo-se em níveis diversos na vida cotidiana, inclusive nas relações de trabalho nas quais atuamos como assistentes sociais.

No entanto, os dados apresentados configuram uma realidade social que é movida por contradições e processos de negação. Assim, há resistências e oposições a esse contexto, há processos de contra-hegemonia em curso na sociedade. É necessário avançar na organização política das esquerdas e das forças progressistas, na defesa da vida, da natureza, da democracia e dos direitos humanos. Nesse sentido, a agenda dos direitos humanos que aponta para as conquistas potencialmente emancipatórias deve ser apropriada como uma plataforma de resistência ao retrocesso e de retomada lenta do acúmulo de forças, na direção de uma sociedade emancipada e livre (Trindade, 2011). 


\section{Referências}

BARROCO, Maria Lucia S. Lukács e a crítica do irracionalismo: elementos para uma crítica da barbárie contemporânea. In: DEL ROYO, Marcos. György Lukács e a emancipação humana. São Paulo: Boitempo, 2013.

BARROCO, Maria Lucia S. Não passarão: ofensiva neoconservadora e Serviço Social. Serviço Social @ Sociedade, São Paulo: Cortez, n. 124: Conservadorismo, lutas sociais e Serviço Social, 2015.

ECO, Umberto. Contra o fascismo. [S. l.]: Lumen, 2018. E-book.

ESCORSIM NETTO, Leila. O conservadorismo clássico: elementos de caracterização e crítica. São Paulo: Cortez, 2011.

KIRK, Russell. The conservative mind: from Burke to Eliot. Washington: Regnery Publishing, 2001.

LUKÁCS, György. A destruição da razão: a trajetória do irracionalismo de Schelling a Hitler. Barcelona: Grijalbo, 1967.

LUKÁCS, György. Concepção aristocrática e concepção democrática de mundo. In: COUTINHO, Carlos Nelson; NETTO, José Paulo (org.). O jovem Marx e outros escritos de filosofia. Rio de Janeiro: Editora UFRJ, 2007.

NETTO, José Paulo. O que é marxismo. São Paulo: Brasiliense, 2006. (Coleção Primeiros passos).

PACHUKANIS, Evguiéni B. Fascismo. São Paulo: Boitempo, 2020.

PAXTON. Robert O. A anatomia do fascismo. São Paulo: Paz e Terra, 2007.

SOARES, Luís Eduardo. Dentro da noite feroz: o fascismo no Brasil. São Paulo: Boitempo, 2020.

STANLEY, Jason. Como funciona o fascismo: a política do "nós" e "eles". Porto Alegre: L\&PM, 2019.

TRINDADE, José Damião de Lima. Os direitos humanos na perspectiva de Marx e Engels: emancipação política e emancipação humana. São Paulo: Alfa-Ômega, 2011.

\section{Sobre a autora}

Maria Lúcia da Silva BarRoco - Assistente social, professora de Ética e Serviço Social, coordenadora do Núcleo de Estudos e Pesquisa em Ética e Direitos Humanos (NEPEDH).

E-mail: barroco.lucia@gmail.com 